Огляди літератури, оригінальні дослідження, погляд на проблему, випадок з практики, короткі повідомлення удК 616-037+618.2-082+618.77+616.36-008.6

DOI 10.11603/1811-2471.2020.v.i1.11074

\title{
ОСОБЛИВОСТІ ГОРМОНАЛЬНОГО ГОМЕОСТАЗУ ЖІНОК ІЗ БЕЗПЛІДДЯМ ТА ВНУТРІШНЬОПЕЧІНКОВИМ ХОЛЕСТАЗОМ
}

\author{
๑Ебає Нсан Еком Нсед, О. Г. Бойчук \\ ДВНЗ «Івано-Франківський національний медичний університет»
}

РЕзЮМЕ. Мета дослідження - вивчити особливості гормонального гомеостазу жінок із безпліддям після застосування допоміжних репродуктивних технологій та внутрішньопечінковим холестазом.

Матеріал і методи. Проведено вивчення гормонального профілю 30 пацієнток із внутрішньопечінковим холестазом (група 1), 30 - з безпліддям без внутрішньопечінкового холестазу (група 2) і 20 жінок контрольної групи.

Визначення гормонів сироватки крові здійснювали за допомогою стандартних наборів для імунорадіометричного визначення.

Результати. Важливе значення для оцінки репродуктивної функції мають не тільки абсолютні величини ФСГ та ЛГ, а й їх збалансованість. При порівняльному аналізі співвідношення ЛГ/ФСГ у жінок з безпліддям та пацієнток контрольної групи в динаміці МЦ достовірне зростання показника було зареєстроване у жінок основних груп у фолікулінову фазу МЦ $((1,91 \pm 0,08)$ МО/л у пацієнток з гепатобіліарними порушеннями проти $(1,47 \pm 0,06)$ та $(1,19 \pm 0,08)$ МО/л у жінок 2-ї та контрольної груп відповідно, p<0,05). Рівень ПРл, за нашими спостереженнями, був достовірно підвищеним у пацієнток 1-ї групи, порівняно з жінками контрольної групи $((9,11 \pm 0,18)$ проти $(8,43 \pm 0,22)$ нг/мл, $\mathrm{p}<0,05)$.

Середнє значення рівня Е2 у сироватці крові пацієнток з безпліддям на 5-й день МЦ достовірно перевищувало відповідне значення жінок контрольної групи $(p<0,05)$. Середній рівень П на 21-й день МЦ у жінок 1-ї та 2-ї груп був достовірно знижений, порівняно з пацієнтками контрольної групи ( $<0,05)$, причому за наявності внутрішньопечінкового холестазу рівень П був достовірно зниженим і відносно показника жінок з безпліддям без ознак таких порушень $(p<0,05)$. Рівень Тв у жінок з безпліддям обох основних груп суттєво перевищував такий у пацієнток контрольної групи $(p<0,05)$.

У жінок з безпліддям після застосування допоміжних репродуктивних технологій і наявністю внутрішньопечінкового холестазу відмічені більш виражені ознаки загрози переривання вагітності на тлі дисбалансу прогестеронів та естрогенів у бік гіперестрогенії, що доведено результатами досліджень рівня гормонів у крові (зниження співвідношення прогестерон/естрадіол до $(3,1 \pm 0,21)$ проти $(6,74 \pm 0,87)$ МО/л у вагітних з непліддям після ДРТ без патології печінки, $p<0,05)$.

Висновки. Отже, при дослідженні гормонального статусу у жінок з безпліддям та захворюваннями гепатобіліарної системи встановлено дисбаланс гонадотропних та статевих гормонів, який вказує на певну прогестеронову недостатність, ознаки гіперестрогенемії, гіперандрогенемії та гіперпролактинемії й більш виражені ознаки загрози переривання вагітності.

КлючОВІ СлОВА: вагітність; непліддя; внутрішньопечінковий холестаз; гормональний гомеостаз.

Вступ. Проблема безпліддя доволі поширена в усьому світі. Багато років показник частоти безплідних шлюбів у різних регіонах світу залишається в межах 8-18 \% і не має тенденції до зниження.

Порушення гормонального фону пов'язане не тільки з репродуктивною патологією, а й впливає на функції багатьох органів і систем. Найчастіше порушуються метаболічні функції печінки. Патологічною основою для цього $\epsilon$ існування в організмі функціональної метаболічної системи «гіпоталамус-гіпофіз-яєчники-печінка» $[1,13,15,20]$.

Тісні функціональні взаємозв'язки стану печінки та рівня жіночих статевих гормонів, поєднання їх порушень, а також застосування при лікуванні безпліддя гормональної терапії, яка негативно впливає на діяльність печінки, пояснюють необхідність вивчення стану гормонального гомеостазу у жінок з безпліддям та захворюваннями гепатобіліарної системи до лікування безпліддя, після лікування та при вагітності, що настала внаслідок застосування ДРТ $[4,13,16,19]$.

Стан репродуктивного здоров'я жінки обумовлений різноманітними факторами, серед яких значне місце належить соматичним захворюванням $[2,21,22]$, зокрема патології гепатобіліарної системи, що на сьогоднішній день визнається багатьма авторами, проте конкретні механізм впливу на перебіг вагітності, що наступила внаслідок допоміжних репродуктивних технологій, мало вивчені і не до кінця визначені. $€$ дані про вплив патології печінки на успішність застосування ДРТ при лікуванні безпліддя. 3 іншого боку, відомий також негативний вплив на печінку гормональної та іншої терапії, яка застосовується у методиках ДРТ [4, $10,15,20]$.

Мета дослідження - вивчення особливості гормонального гомеостазу жінок з безпліддям після застосування допоміжних репродуктивних технологій та внутрішньопечінковим холестазом. 
Огляди літератури, оригінальні дослідження, погляд на проблему, випадок з практики, короткі повідомлення

Матеріал і методи дослідження. Було проведено вивчення гормонального профілю 30 пацієнток з наявністю внутрішньопечінкового холестазу (група 1), 30 - з безпліддям без наявності внутрішньопечінкового холестазу (група 2) i 20 жінок контрольної групи.

Для визначення вмісту гіпофізарних гормонів - лютеїнізуючого гормону (ЛГ), фолікулостимулюючого гормону (ФСГ), пролактину (ПРЛ), стероїдних гормонів - вільного тестостерону (Тв), естрадіолу $\left(E_{2}\right)$, прогестерону $(П)$, плацентарного лактогену (Пл) у сироватці периферійної крові використовували радіоімунологічні методи. Кров для визначення гормонів забирали на 5-й, 14-й та 21-й день менструального циклу (МЦ) та 4-12 тиж- ні вагітності. Визначення гормонів сироватки крові здійснювали за допомогою стандартних наборів для імунорадіометричного визначення.

Результати й обговорення. Як видно з даних, наведених у таблиці 1, при аналізі вмісту гонадотропних гормонів у сироватці крові виявлено, що у пацієнток 1 та 2 груп у фолікулінову фазу менструального циклу рівень ФСГ суттєво не відрізнявся від показника жінок групи контролю: (p>0,05), тоді як концентрація Лг була суттєво підвищеною, причому у жінок з внутрішньопечінковим холестазом вона був достовірно вищою за показник жінок без таких порушень $((8,70 \pm 0,11)$ МО/л проти $(6,35 \pm$ $0,23)$ МО/л та $(5,03 \pm 0,15)$ МО/л у жінок 2-ї та контрольної груп, $р<0,05)$.

Таблиця 1. Рівні гонадотропних гормонів у обстежених пацієнток в динаміці менструального циклу

\begin{tabular}{|l|c|c|c|c|}
\hline \multirow{2}{*}{ Показник } & \multirow{2}{*}{ День циклу } & \multicolumn{3}{|c|}{ Група обстежених } \\
\cline { 2 - 4 } & & $1, \mathrm{n}=30$ & $2, \mathrm{n}=30$ & контроль, $\mathrm{n}=20$ \\
\hline \multirow{3}{*}{ ФСГ, МО/л } & 5 & $4,54 \pm 0,11$ & $4,32 \pm 0,14$ & $4,20 \pm 0,14$ \\
\cline { 2 - 5 } & 14 & $11,15 \pm 0,12^{1,2}$ & $11,92 \pm 0,28^{1}$ & $3,83 \pm 0,33$ \\
\cline { 2 - 5 } & 21 & $3,51 \pm 0,04$ & $3,52 \pm 0,07$ & $5,03 \pm 0,15$ \\
\cline { 2 - 5 } & 5 & $8,70 \pm 0,11^{1,2}$ & $6,35 \pm 0,23^{1}$ & $45,50 \pm 1,17$ \\
\cline { 2 - 5 } & 21 & $36,98 \pm 0,34^{1}$ & $37,51 \pm 0,67^{1}$ & $1,19 \pm 0,08$ \\
\hline \multirow{2}{*}{ ЛГ/ФСГ } & 5 & $6,05 \pm 0,16^{1}$ & $6,31 \pm 0,21$ & $3,66 \pm 0,11$ \\
\cline { 2 - 5 } & 14 & $1,91 \pm 0,08^{1,2}$ & $1,47 \pm 0,06^{1}$ & $1,92 \pm 0,08$ \\
\cline { 2 - 5 } & 21 & $3,51 \pm 0,08$ & $3,48 \pm 0,13$ & $8,43 \pm 0,22$ \\
\hline
\end{tabular}

Примітки: ${ }^{1}$ - різниця відносно показника жінок контрольної групи достовірна $(p<0,05)$;

2 - різниця відносно показника пацієнток 2-ї групи достовірна (p<0,05).

Рівень ПРЛ, за нашими спостереженнями, був достовірно підвищеним у пацієнток 1-ї групи відносно жінок контрольної групи $((9,11 \pm 0,18)$ нг/мл проти $(8,43 \pm 0,22)$ нг/мл, $р<0,05)$. Такі зміни гонадотропних гормонів вказують на ознаки гіперандрогенемії. Важливе значення для оцінки репродуктивної функції мають не тільки абсолютні величини ФСГ та ЛГ, а й їх збалансованість. При порівняльному аналізі співвідношення ЛГ/ФСГ у жінок 3 безпліддям та пацієнток контрольної групи в динаміці МЦ достовірне зростання показника було зареєстроване у жінок основних груп в фолікулінову фазу МЦ $((1,91 \pm 0,08)$ МО/л у пацієнток з гепатобіліарними порушеннями проти $(1,47 \pm 0,06) \mathrm{MO} / л$ та $(1,19 \pm 0,08)$ МО/л у жінок 2-ї та контрольної груп відповідно, p<0,05), що відповідає даним літератури про зв'язок гіперпролактинемії з оваріальними гіперандрогенеміями.

У період овуляції рівень ФСГ та лГ у жінок основних груп був достовірно меншим за такий в контролі $(p<0,05)$. У середню лютеїнову фазу МЦ відмічено достовірне зниження ЛГ у жінок 1-ї групи. При аналізі співвідношення лГ/ФСГ у періоді ову- ляції та ранню лютеїнову фазу МЦ не зареєстровано достовірних відмінностей значення показника між групами обстежених жінок.

У пацієнток з безпліддям реєструвалися відхилення продукції статевих гормонів, порівняно $з$ контролем, більш виражені в середню лютеїнову фазу (табл. 2). Середнє значення рівня $\mathrm{E}_{2}$ у сироватці крові пацієнток з безпліддям на 5-й день МЦ достовірно перевищувало відповідне значення жінок контрольної групи ( $<<0,05)$, на 21-й день МЦ рівень показника у жінок контрольної групи достовірно підвищився, у жінок другої групи також дещо підвищився, а у пацієнток 1-ї групи навіть знизився і був достовірно зменшеним, порівняно з показником жінок контрольної групи ( $<<0,05)$.

Середній рівень П на 5-й день МЦу жінок обстежених груп достовірно не відрізнявся, на 21-й день МЦу жінок 1-ї та 2-ї груп був достовірно нижчим за такий у пацієнток контрольної групи $(p<0,05)$, причому при наявності гепатобіліарних порушень рівень П був достовірно зниженим і відносно показника жінок з безпліддям без ознак таких порушень $(p<0,05)$. Співвідношення $П / E_{2}$ у пацієнток 3 
Огляди літератури, оригінальні дослідження, погляд на проблему, випадок з практики, короткі повідомлення безпліддям на 5-й день МЦ було дещо меншим за відповідне значення жінок контрольної групи, тоді як в ранню лютеїнову фазу (21 день МЦ) воно було суттєво зниженим як у жінок обох основних груп (p>0,05), так і у жінок 1-ї групи відносно жінок 2-ї групи (р>0,05), що свідчить про дисбаланс статевих гормонів (певну прогестеронову недостатність та гіперестрогенемію). Рівень Тв у жінок з безпліддям обох основних груп суттєво перевищував такий у пацієнток контрольної групи $(p<0,05)$.

Таблиця 2. Рівні статевих стероїдів у обстежених пацієнток в динаміці менструального циклу

\begin{tabular}{|c|c|c|c|c|}
\hline \multirow{2}{*}{ Показник } & \multirow{2}{*}{ День циклу } & \multicolumn{3}{|c|}{ Група обстежених } \\
\hline & & $1, n=30$ & $2, n=30$ & контроль, $\mathrm{n}=20$ \\
\hline \multirow[t]{2}{*}{$\mathrm{E}_{2}$, нмоль/л } & 5 & $0,411 \pm 0,009^{1}$ & $0,392 \pm 0,011^{1}$ & $0,329 \pm 0,015$ \\
\hline & 21 & $0,366 \pm 0,014^{1}$ & $0,402 \pm 0,018$ & $0,441 \pm 0,019$ \\
\hline \multirow[t]{2}{*}{ П, нмоль/л } & 5 & $2,21 \pm 0,07$ & $2,30 \pm 0,15$ & $2,34 \pm 0,20$ \\
\hline & 21 & $37,10 \pm 0,54^{1,2}$ & $47,26 \pm 1,04^{1}$ & $54,88 \pm 1,22$ \\
\hline \multirow[t]{2}{*}{$\Pi / E$} & 5 & $5,35 \pm 0,9$ & $5,88 \pm 1,0$ & $7,11 \pm 0,7$ \\
\hline & 21 & $101,37 \pm 1,8^{1,2}$ & $117,3 \pm 2,5^{1}$ & $128,7 \pm 4,2$ \\
\hline ТВ, нг/Мл & 5 & $2,19 \pm 0,08^{1}$ & $1,99 \pm 0,15^{1}$ & $1,61 \pm 0,11$ \\
\hline
\end{tabular}

Примітки: ${ }^{1}$ - різниця відносно показника жінок контрольної групи достовірна $(p<0,05)$;

2 - різниця відносно показника пацієнток 2 -ї групи достовірна $(p<0,05)$.

Перебіг вагітності після лікування безпліддя із застосуванням ДРТ характеризується високою частотою розвитку ускладнень (невиношування вагітності, затримка росту плода, плацентарна недостатність), що обумовлено, зокрема, гормональним дисбалансом, в умовах якого формується і розвивається фетоплацентарний комплекс.
Вивчення гормонального фону в сироватці крові обстежених жінок у ранні терміни вагітності (6-10 тижнів) показало (табл. 3), що рівень прогестерону в сироватці крові жінок з наявністю внутрішньопечінкового холестазу був достовірно зниженим як відносно жінок контрольної групи, так і жінок без порушень функції печінки, що відповідає стану загрози переривання вагітності.

Таблиця 3. Гормональний профіль вагітних після застосування допоміжних репродуктивних технологій

\begin{tabular}{|l|c|c|c|}
\hline \multirow{2}{*}{\multicolumn{1}{|c|}{ Показник }} & \multicolumn{2}{|c|}{ Група обстежених } \\
\cline { 2 - 4 } & $1, \mathrm{n}=30$ & $2, \mathrm{n}=30$ & контроль, $\mathrm{n}=20$ \\
\hline Прогестерон, нмоль/л & $31,67 \pm 5,24^{1,2}$ & $54,35 \pm 6,16^{1}$ & $92,14 \pm 4,23$ \\
\hline Естрадіол, нмоль/л & $9,87 \pm 0,019^{1,2}$ & $8,82 \pm 0,015$ & $6,48 \pm 0,012$ \\
\hline П/Е & $3,10 \pm 0,21^{1,2}$ & $6,74 \pm 0,87$ & $15,20 \pm 0,68$ \\
\hline Плацентарний лактоген, мг/л & $0,35 \pm 0,07$ & $0,63 \pm 1,20$ & $0,94 \pm 0,08$ \\
\hline
\end{tabular}

Примітки: ${ }^{1}$ - різниця відносно показника жінок контрольної групи достовірна $(p<0,05)$;

2 - різниця відносно показника пацієнток 2 -ї групи достовірна $(p<0,05)$.

При цьому відмічено суттєве зростання рівня в крові естрадіолу у жінок з внутрішньопечінковим холестазом і, відповідно, зниження майже у 5 разів співвідношення прогестерон/естрадіол, що також вказує на загрозу невиношування вагітності, яка у різній мірі відмічалась практично у всіх жінок після ДРТ. Виявлене також зниження плацентарного лактогену. У сукупності такі зміни гормонального фону при вагітності можуть свідчити про початкові ознаки формування плацентарної недостатності. Отже, ембріональний період росту плода відбувався в умовах несприятливого гормонального фону.

Висновки. 1. При дослідженні гормонального статусу у жінок з безпліддям та захворюваннями гепатобіліарної системи встановлено дисба- ланс гонадотропних та статевих гормонів, який вказує на певну прогестеронову недостатність, ознаки гіперестрогенемії, гіперандрогенемії та гіперпролактинемії.

2. У вагітних жінок після застосування допоміжних репродуктивних технологій з наявністю внутрішньопечінкового холестазу відмічені більш виражені ознаки загрози переривання вагітності на тлі дисбалансу прогестеронів та естрогенів у бік гіперестрогенемії, що доведено результатами досліджень рівня гормонів у крові.

Перспективи подальших досліджень. Перспективними $є$ вивчення гормональнихта метаболічних порушень у пацієнток з безпліддям і гепатобіліарною патологією, розробка методів попередньої підготовки до програм допоміжних репродуктив- 
Огляди літератури, оригінальні дослідження, погляд на проблему, випадок з практики, короткі повідомлення них технологій, виявлення та корекція факторів, що негативно впливають на прогноз настання і результат очікуваної вагітності, оптимізація схем ін-

дукції суперовуляції і методів ведення ранніх етапів вагітності, що дозволить підвищити ефективність використання ДРТ у даної категорії пацієнток.

\section{ЛІТЕРАТУРА}

1. Стратегія ВООЗ у галузі репродуктивного здоров'я, 2004. - Режим доступу : http://whqlibdoc.who.int/ hq/2004/WHO_RHR_04.8_rus.pdf?ua=1

2. Юзько О. М. Допоміжні репродуктивні технології в Україні: вагітність, пологи, новонароджені / О. М. Юзько // Жіночий лікар. - 2013. - № 4. - С. 52-53.

3. Овсянникова Т. В. Современные принципы диагностики и лечения бесплодного брака / Т. В. Овсянникова, Д. П. Камилова, А. А. Феоктистов // Гинекология. -2009 . - № 4. - С. 30-33.

4. Допоміжні репродуктивні технології в Україні / О. М. Юзько, Н. Я. Жилка, Н. Г. Руденко [та ін.] // Жіночий лікар. - 2007. - № 3. - С. 8.

5. Структура женского бесплодия и прогноз восстановления репродуктивной функции при использовании современных эндоскопических методов / В. И. Кулаков, Ф.А.Маргиани, Т. А. Назаренко, Л. В. Дубницкая // Акушерство и гинекология. - 2001. - № 3. - С. 33-36.

6. Мишиева Н. Г. Бесплодие у женщин позднего репродуктивного возраста : принципы диагностики и лечения в зависимости от овариального резерва : автореф. дис. на соискание ученой степени д-ра мед. наук / Н. Г. Мишиева. - М., 2008. - 47 с.

7. Якісне клінічне лікування за допомогою репродуктивних технологій. Програмний документ ESHRE, 2008. - Режим доступу: http://www.eshre.com/binarydata. aspx?typedoc/Good_clinical_treatment_ESHRE_position_ paper_UKRAINIAN.pdf.

8. Скрипник І. М. Клінічна гепатологія / І. М. Скрипник, Т. В. Мельник, М. М. Потяженко. - Полтава : Дивосвіт, 2007. -425 с.

9. Подымова С. Д. Болезни печени. Изд. 4-е, перераб. / С. Д. Подымова. - М. : Медицина, 2005. - 704 с.

10. Караченцев А. Н. Гепатобилиарная система как мишень нежелательных эффектов лекарственных эстрогенов и гестагенов / А. Н. Караченцев // Российский вестник акушера-гинеколога. - 2004. - № 6. - С. 20-25.

11. Identifying genetic risk factors for serious adverse drug reactions: curent progress and challenges / R. A. Wilke, D. W. Lin, D. M. Roden [et al.] // Nat. Rev. Drug. Discov. 2007. - № 11. - P. 904-916.

12. Upadhyay R. D. Proteomics in reproductive biology: beacon for unraveling the molecular complexities /

\section{REFERENCES}

1. (2004). Stratehiia VOOZ v haluzi reproduktyvnoho zdorovia [WHO Reproductive Health Strategy]. Retrieved from: http://whqlibdoc.who.int/hq/2004/WHO_RHR_04.8_ rus.pdf?ua $=1$

2. Yuzko, O.M. (2013). Dopomizhni reproduktyvni tekhnolohii v Ukraini: vahitnist, polohy, novonarodzheni [Auxiliary reproductive technologies in Ukraine: pregnan-
R. D. Upadhyay, N. H. Balasinor, A. V. Kumar // Biochim. Biophys. Acta. - 2013. - Vol. 1834 (1). - P. 8-15.

13. Дубоссарская Ю. А. Патология гепатобилиарной системы в практике гинеколога / Ю. А. Дубоссарская // Медицинские аспекты здоровья женщины. 2010. - № 3 (30). - C. 12-19.

14. Amino acid-dependent activation of liver estrogen receptor Alpha integrates metabolic and reproductive functions via IGF-1 / T. S. Della, G. Rando, C. Meda [et al.] // Cell Metabolism. - 2011. - No. 13 (2). - P. 205-214.

15. Lipin1 regulation by Estrogen in uterus and liver: Implications for diabetes and fertility / P. M. Gowri, S. Sengupta, S. Bertera, Benita S. Katzenellenbogen // Endocrinology. - 2007. - Vol. 148, Issue 8. - P. 3685-3693. URL : https://doi.org/10.1210/en.2006-1728

16. Bełtowski J. Liver $X$ receptor (LXR) and the reproductive system - a potential novel target for therapeutic intervention / J. Bełtowski, A. Semczuk // Pharmacological Reports. - 2010. - No. 62 (1). - P. 15-27.

17. Игнатова Т. М. Заболевания печени у беременных / Т. М. Игнатова // Медицинский вестник Северного Кавказа. - 2009. - № 2. - С. 88-93.

18. Bacq Y. Liver diseases unique to pregnancy: a 2010 update / Y. Bacq // Clin. Res. Hepatol. Gastroenterol. 2011. - No. 35. - P. 182-193.

19. Особливості етіології та патогенезу внутрішньопечінкового холестазу вагітних / О. І. Федів, С. В. Вірста, Н. С. Спащук, Т. В. Заболотна // Клінічна та експериментальна патологія. - 2013. - Т. 12, № 1. - С. 197-200.

20. Крамарев С. А. Современные гепатопротекторы в гепатологии / С. А. Крамарев // Дитячий лікар. 2011. - № 1. - С. 5-9.

21. Вивчення впливу віку та індексу коморбідності на ризик тромботичних ускладнень у хворих на рак ендометрія на доопераційному етапі / Б. Д. Кривокульський, І. В. Жулкевич, Д. Б. Кривокульський, Л. В. Шкробот // Вісник наукових досліджень. - 2018. - № 2. C. $150-154$.

22. Peculiarities of uterine cavity biocenosis in patients with different types of endometrial hyperproliferative pathology / N. Y. Horban, I. B. Vovk, T. O. Lysiana [et al.] // Journal of Medicine and Life. - 2019. - Vol. 12 (3). P. 266-270. 
Огляди літератури, оригінальні дослідження, погляд

4. Yuzko, O.M., Zhylka, N.Ya., Rudenko, N.H., Aloshyna, H.M., \& Yuzko, T.A. (2007). Dopomizhni reproduktyvni tekhnolohii v Ukraini [Auxiliary reproductive technologies in Ukraine]. Zhinochyi likar - Women's Doctor, 3, 8 [in Ukrainian].

5. Kulakov, V.I., Margiani, F.A., Nazarenko, T.A., \& Dubnitskaya, L.V. (2001). Struktura zhenskogo besplodiya i prognoz vosstanovleniya reproduktivnoy funktsii pri ispolzovanii sovremennykh endoskopicheskikh metodov [The structure of female infertility and the prognosis of the restoration of reproductive function using modern endoscopic methods]. Akusherstvo i ginekologiya-Obstetrics and Gynecology, 3, 33-36 [in Russian].

6. Mishiyeva, N.G. (2008). Besplodiye u zhenshchin pozdnego reproduktivnogo vozrasta: printsipy diagnostiki i lecheniya v zavisimosti ot ovarialnogo rezerva [Infertility in women of late reproductive age: principles of diagnosis and treatment depending on the ovarian reserve]. Extended abstract of Doctor's thesis. Moscow [in Russian].

7. (2008). Yakisne klinichne likuvannia za dopomohoiu reproduktyvnykh tekhnolohii [Quality clinical treatment using reproductive technologies]. Programming Document. Retrieved from: http://www.eshre.com/binarydata.aspx? typedoc/Good_clinical_treatment_ESHRE_position_ paper_UKRAINIAN.pdf.

8. Skrypnyk, I.M., Melnyk, T.V., \& Potyazhenko, M.M. (2007). Klinichna hepatolohiya [Clinical hepatology]. Poltava: Dyvosvit [in Ukrainian].

9. Podymova, S.D. (2005). Bolezni pecheni: Izd. 4-ye, pererab. [Liver disease: $4^{\text {th }}$ ed. rev]. Moscow: Meditsina [in Russian].

10. Karachentsev, A.N. (2004). Gepatobiliarnaya sistema kak mishen nezhelatelnykh effektov lekarstvennykh estrogenov i gestagenov [Hepatobiliary system as a target of undesirable effects of drug estrogens and progestogens]. Rossiyskiy vestnik akushera-ginekologa-Russian Bulletin of the Obstetrician-Gynecologist, 6, 20-25 [in Russian].

11. Wilke, R.A., Lin, D.W., Roden, D.M., Watkins, P.B., Flockhart, D., Zineh, I., ..., \& Krauss, R.M. (2007). Identifying genetic risk factors for serious adverse drug reactions: curent progress and challenges. Nat. Rev. Drug Discov., 11, 904-916.

12. Upadhyay, R.D., Balasinor, N.H., \& Kumar, A.V. (2013). Proteomics in reproductive biology: beacon for unraveling the molecular complexities. Biochim. Biophys. Acta, 1834 (1), 8-15.

13. Dubossarskaya, Yu.A. (2010). Patologiya gepatobiliarnoy sistemy $v$ praktike ginekologa [Pathology of the проблему, випадок з практики, короткі повідомлення hepatobiliary system in the practice of a gynecologist]. Meditsinskiye aspekty zdorovya zhenshchiny - Medical Aspects of Women's Health, 3 (30), 12-19 [in Russian].

14. Della Torre, S., Rando, G., Meda, C., Stell, A., Chambon, P., Krust, A., ..., \& Maggi A. (2011). Amino acid-dependent activation of liver estrogen receptor Alpha integrates metabolic and reproductive functions via IGF-1. Cell Metabolism, 13 (2), 205-214.

15. Gowri, P.M., Sengupta, S., Bertera, S., \& Katzenellenbogen, B.S. (2007). Lipin1 regulation by estrogen in uterus and liver: Implications for diabetes and fertility. Endocrinology, 148, 8, 3685-3693. Retrieved from: https://DOI.org/ 10.1210/en.2006-1728

16. Bełtowski, J., \& Semczuk, A. Liver X receptor (LXR) and the reproductive system - a potential novel target for therapeutic intervention. Pharmacological Reports, 62 (1), 15-27.

17. Ignatova, T.M. (2009). Zabolevaniya pecheni u beremennykh [Diseases of the liver in pregnant women]. Meditsinskiy vestnik Severnogo Kavkaza - Medical Bulletin of the North Caucasus, 2, 88-93 [in Russian].

18. Bacq, Y. (2011). Liver diseases unique to pregnancy: a 2010 update. Clin. Res. Hepatol. Gastroenterol., 35, 182-193.

19. Fediv, O.I., Virsta, S.V., Spashchuk, N.S., \& Zabolotna, T.V. (2013). Osoblyvosti etiolohii ta patohenezu vnutrishnopechinkovoho kholestazu vahitnykh [Features of etiology and pathogenesis of intrahepatic cholestasis of pregnant women]. Klinichna ta eksperymentalna patolohiia Clinical and Experimental Pathology, 12, 1, 197-200 [in Ukrainian].

20. Кramarev, S.A. (2011). Sovremennye gepatoprotektory $v$ gepatologii [Modern hepatoprotectors in hepatology]. Dytiachyi likar - Pediatric Doctor, 1, 5-9 [in Russian].

21. Kryvokulskyi, B.D., Zhulkevych, I.V., Kryvokulskyi, D.B., \& Shkrobot, L.V. (2018). Vyvchennia vplyvu viku ta indeksu komorbidnosti na ryzyk trombotychnykh uskladnen u khvorykh na rak endometriia na dooperatsiinomu etapi [Studying the influence of age and comorbidity index on the thrombotic complications risk in patients with endometrial cancer at preoperative stage]. Visnyk naukovykh doslidzhen - Bulletin of Scientific Research, 2, 150-154 [in Ukrainian].

22. Horban, N.Y., Vovk, I.B., Lysiana, T.O., Ponomariova, I.H., \& Zhulkevych, I.V. (2019). Peculiarities of uterine cavity biocenosis in patients with different types of endometrial hyperproliferative pathology. Journal of Medicine and Life, 12 (3), 266-270.

\section{ОСОБЕННОСТИ ГОРМОНАЛЬНОГО ГОМЕОСТАЗА ЖЕНЩИН С БЕСПЛОДИЕМ И ВНУТРИПЕЧЕНОЧНЫМ ХОЛЕСТАЗОМ}

\section{๑Ебає Нсан Эком Нсед, А. Г. Бойчук}

ГВУз «Ивано-Франковский национальный медицинский університет»

\footnotetext{
Цель исследования - изучить особенности гормонального гомеостаза женщин с бесплодием после применения вспомогательных репродуктивных технологий и внутрипеченочным холестазом.

Материал и методы. Было проведено изучение гормонального профиля 30 пациенток с внутрипеченочным холестазом (группа 1), 30 - с бесплодием без внутрипеченочного холестаза (2 группа) и 20 женщин контрольной группы.

Определение гормонов сыворотки крови проводилось с помощью стандартных наборов для иммунорадиометрического определения.
} 
Огляди літератури, оригінальні дослідження, погляд на проблему, випадок з практики, короткі повідомлення

Результати. Важное значение для оценки репродуктивной функции имеют не только абсолютные величины ФСГ и ЛГ, но и их сбалансированность. При сравнительном анализе соотношения ЛГ/ФСГ у женщин с бесплодием и пациенток контрольной группы в динамике МЦ достоверный рост показателя был зарегистрирован у женщин основных групп в фоликулиновую фазу МЦ $((1,91 \pm 0,08)$ МЕ/л у пациенток с гепатобилиарными нарушениями против $(1,47 \pm 0,06)$ и $(1,19 \pm 0,08)$ МЕ/л у женщин 2-й и контрольной групп соответственно, p<0,05). Уровень ПРЛ, по нашим наблюдениям, был достоверно повышен у пациенток 1-й группы, относительно женщин контрольной группы $((9,11 \pm 0,18)$ против $(8,43 \pm 0,22)$ нг/мл, $\mathrm{p}<0,05)$.

Среднее значение уровня Е2 в сыворотке крови пациенток с бесплодием на 5-й день МЦ достоверно превышало соответствующее значение женщин контрольной группы $(p<0,05)$. Средний уровень П на 21-й день МЦ у женщин 1-й и 2-й групп был достоверно снижен, по сравнению с пациентками контрольной группы (р<0,05), причем при наличии внутрипеченочного холестаза уровень П был достоверно снижен и относительно показателя женщин с бесплодием без признаков таких нарушений $(p<0,05)$. Уровень Тв у женщин с бесплодием обеих основных групп существенно превышал таковой у пациенток контрольной группы ( $<<0,05)$.

У женщин с бесплодием после применения вспомогательных репродуктивных технологий и наличием внутрипеченочного холестаза отмечены более выраженные признаки угрозы прерывания беременности на фоне дисбаланса прогестерона и эстрогенов в сторону гиперэстрогении, что доказано результатами исследований уровня гормонов в крови (снижение соотношения прогестерон/эстрадиол до $(3,10 \pm 0,21)$ против $(6,74 \pm 0,87)$ у беременных с бесплодием после ВРТ без патологии печени, р<0,05).

Выводы. При исследовании гормонального статуса у женщин с бесплодием и заболеваниями гепатобилиарной системы установлен дисбаланс гонадотропных и половых гормонов, который указывает на определенную прогестероновую недостаточность, признаки гиперэстрогении, гиперандрогении и гиперпролактинемии и более выраженные признаки угрозы прерывания беременности.

КЛЮчЕВЫЕ СЛОВА: беременность; бесплодие; внутрипеченочный холестаз; гормональный гомеостаз.

\section{THE PECULIARITIES OF HORMONAL HOMEOSTASIS IN WOMEN WITH INFERTILITY AND INTRAHEPATIC CHOLESTASIS}

\section{@Ebaye Nsan Ekom Nsed, O. H. Boichuk Ivano-Frankivsk National Medical University}

The aim of the study - to examine the peculiarities of hormonal homeostasis in women with infertility treated with assisted reproductive technologies and with concomitant intrahepatic cholestasis.

Material and Methods. We analyzed the hormone profiles of 30 female patients with infertility and intrahepatic cholestasis (Group 1), 30 women with infertility but without intrahepatic cholestasis (Group 2) and 20 women from the reference group.

The levels of hormones in blood serum were measured with the use of standard kits for immunoradiometric assay.

Results and Discussion. Important to the assessment of the reproductive function are not only the absolute values of the follicle-stimulating hormone (FSH) and the luteinizing hormone (LH) but also their balance. The comparative analysis of the LH/FSH ratios in women with infertility and women from the reference group in the course of the menstrual cycle has significantly shown an increase of the said ratio in women from the basic groups in the follicular phase of the menstrual cycle $(1.91 \pm 0.08) \mathrm{IU} / \mathrm{l}$ in patients with the hepatobiliary disorder vs. $(1.47 \pm 0.06)$ and (1.19 \pm 0.08$) \mathrm{IU} / \mathrm{l}$ in women from Group 2 and from the reference group respectively, $p<0.05)$. The prolactin level, according to our findings, is significantly increased in patients from Group 1 in comparison with women from the reference group (9.11 \pm 0.18$)$ vs. $(8.43 \pm 0.22) \mathrm{ng} / \mathrm{ml}, \mathrm{p}<0.05)$.

The average value of the estradiol level in blood serum on the fifth day of the menstrual cycle was significantly higher in women with infertility in comparison with the reference group $(p<0.05)$. The average progesterone level on the $21^{\text {st }}$ day of the menstrual cycle was significantly lower in women from Group 1 and 2 in comparison with the reference group $(p<0.05)$, and still lower in women with intrahepatic cholestasis if compared with women with infertility but without such biliary disorders $(p<0.05)$. The testosterone level in women with infertility from both basic groups is considerably higher than that measured in women from the reference group $(p<0.05)$.

Women with infertility treated with assisted reproductive technologies and with concomitant intrahepatic cholestasis present more apparent signs of threat of abortion, in view of imbalance in progesterone and estrogen levels in favor of hyperestrogenism, which had been proved by the results of examination of the hormone levels in blood (reduction of the progesterone/estradiol ratio to $(3.1 \pm 0.21)$ vs. $(6.74 \pm 0.87)$ in pregnant women with infertility treated with ART but without hepatic pathologies, $p<0.05$ ).

Conclusions. The research of the hormonal status in women with infertility and concomitant hepatobiliary diseases found an imbalance in gonadotropic and sex hormones, which manifests itself in progesterone insufficiency, signs of hyperestrogenism, hyperandrogenism and hyperprolactinemia as well as more apparent signs of threat of abortion.

KEY WORDS: pregnancy; infertility; intrahepatic cholestasis; hormonal homeostasis. 